\title{
Nutrition Education intervention in dyslipidemic children and adolescent with insulin-dependent diabetes mellitus (IDDM)
}

\author{
Asmaa m. Abdallah*, Zainab B* and Mohamed M. A. Shahat** \\ * Clinical Nutrition Department, Nutrition Institute. \\ **Department of Zoology, Faculty of Science, AL-Azhar University (Assiut)
}

\begin{abstract}
Background: Diabetes mellitus is the most common endocrine metabolic disorder of childhood and adolescence with important consequences for physical and emotional development.

Aim of the study: This study was designed to detect the effect of diet therapy (through nutrition education program) on lipid profile and blood glucose level in diabetic children.

Subjects and Methods: The study was carried on 45 diabetic children aged between 8-15 years old at diabetic nutrition clinic of nutrition institute in Cairo from 2003-2005. Children included in the study were divided into two groups: insulin dependent dyslipidemic group (IDDM) (diet control/ group) and insulin dependent non dyslipidemic (control group). All were subjected to full dietetic history by the 24 hour recall for 3 days, thorough clinical examination, they were evaluated for plasma lipids, lipoproteins, fasting blood glucose (FBG) and glycated hemoglobin $\left(\mathrm{HbA}_{1 \mathrm{c})}\right.$ levels. The dyslipidemic were measured after three months for the previously measured parameters. The nutrition education process was performed and continued on weekly intervals for three months.

Results: There was significant decrease in serum cholesterol and triglyceride levels in the study group after the program, and insignificant increase in serum HDL and decrease in serum LDL. Also, there was insignificant decrease in FBG but there was statistically significant decrease in $\mathrm{HbA} 1$ after the program. These changes occurred in parallel with increases in intakes of protein and total calories with adequate carbohydrate and sometimes a reduction in intakes of total fat. Conclusion: Nutrition therapy for children with IDDM is essential to improve measures of glycemic control and lipoprotein mediated risk for dyslipidemia. More innovative approaches to achieve lifestyle changes are required to meet current recommendations which are likely to produce greater beneficial changes than those observed in this study.
\end{abstract}

Key words:_ IDDM- Children- dyslipidemia- Diet control

\section{Introduction}

Diabetes mellitus is a syndrome of disturbed energy homeostasis caused by deficiency of insulin or of its action and resulting in abnormal metabolism of carbohydrates, protein and fat. It is the most common endocrine metabolic disorder of childhood and adolescence with important consequences for physical and emotional development. IDDM is characterized by severe insulinopenia and dependence on exogenous insulin to prevent ketosis and preserve life (Sperling, 1996 and Franz et $a l .$, 2002).

Incidence studies of diabetes for IDDM denote $8.3 \%$ and $7.6 \%$ per 100.00 populations below age 15 years, at urban and rural communities respectively. The commonest age of onset of IDDM falls between 12-14 years, and there appears to be a tendency for IDDM to develop at a younger age among Egyptians (Ibrahim and Arab, 1992).

Hypercholesterolemia and hypertriglyceridemia were more frequent among the IDDM patients (Torres et al., 1997). The dyslipidemia of diabetes also includes low levels of high-density lipoprotein (HDL) cholesterol, alterations in the composition of low-density lipoprotein (LDL), predominance of triglyceride-rich small dense LDL particles, and an increase in apolipoproteins B\&E. The potential for glycation and oxidation of all lipoproteins (Lp) classes is enhanced, and alterations of 
lipid composition are manifold (Barakat et al., 1990).

Dyslipidemia is a preventable major risk factor for coronary heart disease (CHD). Despite an increased risk of CHD in type 1 diabetes, little is known concerning awareness and adequacy of dyslipidemia treatment in this population (Wadwa et al., 2005).

The Pittsburgh Diabetes Clinic found differences between diabetic patients and their siblings in an HDL subfraction, but other lipid levels were not significantly different (Orchard, et al., 2001). Presence of dyslipidemia was defined by LDL $\geq 130$ $\mathrm{mg} / \mathrm{dl}, \mathrm{HDL}<40 \quad \mathrm{mg} / \mathrm{dl}$, total cholesterol $\geq$ $200 \mathrm{mg} / \mathrm{dl}$, or triglycerides $\geq 150 \mathrm{mg} / \mathrm{dl}$ (Wadwa et al., 2005).

Optimal lipid levels for those with diabetes: LDL <100 mg/dl HDL > $35 \mathrm{mg} / \mathrm{dl}$ and Triglycerides $<150 \mathrm{mg} / \mathrm{dl}$ (Kavey et al., 2003).

Youth with dyslipidemia are first treated with a diet reduced in total fat, saturated fat, and cholesterol. The intake of complex carbohydrates is increased while that of simple sugars is decreased. No decrease in total protein is recommended. While, Calories are sufficient to maintain normal growth and development (Perry et al., 2008)

Dietary recommendation for those with dyslipidemia is reducing total fat to less than $20 \%$ of total calories and cholesterol to less than $200 \mathrm{mg} /$ day $(<150$ $\mathrm{mg}$ /day for the ADA) (American diabetes association (ADA,1987 and the national cholesterol education program (NCEP), 1988).

Studies of patients with IDDM have shown that replacing foods high in saturated fat with foods containing predominately complex carbohydrate lower both total and low density lipoprotein (LDL) cholesterol levels. However, decrease in high density lipoprotein (HDL) cholesterol concentration has been observed in some studies (Abbott et al., 1990). For those who cannot follow a high-carbohydrate diet consumption of diet high in monounsaturated fatty acids resulted in reduction in a triglyceride and LDL concentrations and produced less lowering effect on HDL concentration (Barbara and James, 1994).
Increases in $\mathrm{n}-3$ polyunsaturated fatty acids that predominately found in fish oils, have a hypotriglyceridemic action in non-diabetic persons. In studies of diabetic patients, fish oil supplementation has had an adverse effect on glycemic control. Thus, supplements in diabetic patients are not recommended, although they should be encouraged to eat fish (Ronald and Gordon, 1994).

\section{Subjects and Methods}

This study was carried on diabetic children aged between 8-15 years old 30 Diabetic dyslipidemic IDDM patients and 15 Diabetic non dyslipidemic IDDM patients. All were under regular insulin regimen.

Children with either mental or physical disabilities, abnormal neurological findings, Children suffering from diabetic comas during the programs (for intervention program Patients only) were excluded.

All individuals were subjected to: Full medical history, clinical examination, dietary assessment and laboratory investigations. The diabetic non-Dyslipidemic was used as control group. Lipid analysis (Serum cholesterol, high and low density lipoprotein cholesterol and triglycerides) and blood analysis [HemoglobinA1 (HbAlc) and fasting blood glucose (FBG) level] were done for the dyslipidemic before and after treatment period and for the control were done at the start of the study.

Serum cholesterol \& triglyceride was determined by enzymatic colorimetry

\section{Serum lipid assay cut - off (mg/dl):}

- Total cholesterol is $155-202$ for $10-14$ years and 146-203 for 14-19 years (Allain, 1974).

- HDL-cholesterol is 40-74 for 10-14 yrs and 34-74 for 14-19yrs (Burstein, 1970).

- LDL-cholesterol is $94-136$ for $10-14 y r s$ and 93-137 for 14-19yrs,

LDL-cholesterol calculated as follows LDL $=$ total cholesterol- $[$ HDL- cholesterol + TG/5] (Friedewald et al., 1972).

-Triglycerides (TG) are 59-131 for 10-14yrs and 68-148 for14-19yrs (Fossati and Prencipe, 1982). 
- Blood glucose: monitoring performed by blood strips (heamoglukotest, Boehringer- Manheim, Germany) and Trinder (1969). Normal range $=70-105$ $\mathrm{mg} / \mathrm{dl}$.

Hemoglobin A1:-estimated by using cation exchange chromatography method (Abraham et al., 1978). Diabetic: good control $=7.5-8.9 \%$

Fair control $=9-10 \%$

Poor control $=$ above $10.0 \%$. The minimum time interval for estimation of glycated HbA1c was 3 months.

\section{Dietary assessment:}

The daily food intake (24 hours recall) for each child was calculated for total energy, protein, lipids, carbohydrates and fibers before and after nutrition education program (NEP) for the Dyslipidemic group. The nutrition education process was performed and continued for three months at weekly interval. It was conducted into four stages: Nutrition assessment, planning, Implementation and Re-assessment.

\section{Nutrition Education Program (NEP):}

The objective of NEP was to provide simple knowledge about diabetes and treatment plan, nutritional management, distribution of food and food groups and overall health of diabetic child.

The program was applied as one hour sessions once weekly for one month after Pre-assessment test. Then, two days weekly for another two months were fixed for individualized educational technique to give chance to answer and explain all questions raised by children or their parents.

\section{Statistical analysis:}

Data is presented as frequency distribution percent, means and standard deviation. Analysis by t-test and 0.05 was used as cut-off point for significant result (Dean et al., 1997 and Spss, 2001).

\section{Results}

Table (1) shows mean and standard deviation (SD) of the different measured parameters (cholesterol, triglycerides, HDL, LDL, FBG \& HbAlc) for all the studied individuals before diet therapy program. The diabetic dyslipidemic showed significantly higher mean values levels than the diabetic non dyslipidemic for all parameters except the FBG\&HbA1c, and the difference was not significant. A poor control of diabetes, reflected by high levels of glycosylated hemoglobin and/or high fasting blood glucose, was associated with statistically significant increases in total cholesterol, LDL-cholesterol and triglycerides, and a reduction in HDLcholesterol.

Table (2) shows comparison between the mean and standard deviation of the measured parameters for the diabetic dyslipidemic patients before and after implementation of diet therapy program , the results showed statistically significant decrease in serum cholesterol $(\mathrm{p}=0.006)$, triglycerides $(\mathrm{p}=0.006)$ and glycosylated hemoglobin $(p=0.001)$ after diet therapy program.

\section{Dietary assessment}

The daily food intake for each child was calculated for total energy, protein, lipids, carbohydrates and fibers before and after nutrition education program (NEP) for the Dyslipidemic group.

Table (3) shows the mean and standard deviation for the calculated daily intake of total energy (kilocalories) according to age for the study group before and after NEP, compared with the recommended dietary allowance (RDA). In the study group the caloric intake was increased in each age group but not statistically significant.

Table (4) shows mean and S.D. of total protein daily intake according to the age among study group before and after NEP, and comparison with the recommended dietary allowance. The protein intake was higher than the RDA in all age groups. After the NEP, the protein intake was insignificantly increased in most age groups.

Table (5) shows mean \& S.D. of calculated daily intake of total lipids according to the age among study group before and after NEP. Lipid intake of the study group was decreased in all age groups but statistically insignificant.

Table (6) shows mean \& S.D. of calculated daily intake of total carbohydrate according to the age among study group 
before and after NEP. Carbohydrate intake adjusted to the recommended level in most age groups, with statistically significant difference in the study group age 1215 years.
Table (7) shows mean \& S.D of total fiber daily intake according to the age among study group before and after NEP. Fiber intake increased significantly after NEP although the consumption was still below the recommended level.

Table (1): Mean and standard deviation of the different measured parameters for all the studied individuals before diet therapy program.

\begin{tabular}{|c|c|c|}
\hline $\begin{array}{l}\text { Baseline characteristics of the } \\
\text { study group }\end{array}$ & $\begin{array}{c}\text { Diabetic Dyslipidemic } \\
\text { Means } \pm \text { SD }\end{array}$ & $\begin{array}{c}\text { Diabetic Non Dyslipidemic } \\
\text { Means } \pm \text { SD }\end{array}$ \\
\hline \multirow{2}{*}{$\begin{array}{l}\text { Serum cholesterol }(\mathrm{mg} / \mathrm{dl}) \\
\mathrm{T} \text { value }(\mathrm{P})\end{array}$} & $219 \pm$ & $144.8 \pm 16.2$ \\
\hline & \multicolumn{2}{|c|}{$9.9(0.001)$} \\
\hline Serum LDL (mg/dl) & $145.5 \pm 25.6$ & \pm 23 \\
\hline $\mathrm{T}$ value $(\mathrm{P})$ & \multicolumn{2}{|c|}{$5.4(0.001)$} \\
\hline \multirow{2}{*}{$\begin{array}{l}\text { Serum HDL (mg/dl) } \\
\mathrm{T}(\mathrm{P})\end{array}$} & $39.9 \pm 11.7$ & \pm 8.4 \\
\hline & \multicolumn{2}{|c|}{$2.54(0.018)$} \\
\hline Serum triglycerides $(\mathrm{mg} / \mathrm{dl})$ & $135.9 \pm 54.2$ & $83.7 \pm 33.5$ \\
\hline $\mathrm{T}$ value $(\mathrm{P})$ & \multicolumn{2}{|c|}{$2.7(0.012)$} \\
\hline \multirow{4}{*}{$\begin{array}{l}\text { Fasting-blood glucose }(\mathrm{mg} / \mathrm{dl}) \\
\text { T value }(\mathrm{P}) \\
\text { Glycosylated hemoglobin \% } \\
\text { T value }(\mathrm{P})\end{array}$} & $174.9 \pm 58.1$ & $167.5 \pm 59.5$ \\
\hline & \multicolumn{2}{|c|}{$0.34(0.737)$} \\
\hline & $10.9 \pm 2$ & $10.4 \pm 1.8$ \\
\hline & \multicolumn{2}{|c|}{$0.64(0.530)$} \\
\hline
\end{tabular}

Table (2): Mean and standard deviation of the different measured parameters for the diabetic dyslipidemic group before and after implementation of nutrition education program.

\begin{tabular}{|c|c|c|}
\hline Measured parameters & $\begin{array}{l}\text { Before NEP } \\
\text { Mean } \pm \text { SD }\end{array}$ & $\begin{array}{l}\text { After NEP } \\
\text { Mean } \pm \text { SD }\end{array}$ \\
\hline Serum cholesterol(mg/dl) & $219 \pm 24$ & $194 \pm 29$ \\
\hline T value $(\mathrm{p})$ & \multicolumn{2}{|c|}{$3.8(0.002)$} \\
\hline Serum LDL(mg/dl) & $145 \pm 25.6$ & $131.7 \pm 31.3$ \\
\hline $\mathrm{T}$ value $(\mathrm{p})$ & \multicolumn{2}{|c|}{$2(0.065)$} \\
\hline Serum HDL $(\mathrm{mg} / \mathrm{dl})$ & $39.9 \pm 11.7$ & $40.8 \pm 4.1$ \\
\hline $\mathrm{T}$ value $(\mathrm{p})$ & \multicolumn{2}{|c|}{$0.40(0.694)$} \\
\hline Serum triglyceride $(\mathrm{mg} / \mathrm{dl})$ & $135.9 \pm 54.2$ & $114.3 \pm 42.5$ \\
\hline $\mathrm{T}$ value $(\mathrm{p})$ & \multicolumn{2}{|c|}{$3.2(0.006)$} \\
\hline Fasting blood glucose $(\mathrm{mg} / \mathrm{dl})$ & $174.9 \pm 58.1$ & $160.6 \pm 43.0$ \\
\hline $\mathrm{T}$ value $(\mathrm{p})$ & \multicolumn{2}{|c|}{$0.81(0.429)$} \\
\hline Glycosylated hemoglobin \% & $10.9 \pm 2$ & $10.3 \pm 1.7$ \\
\hline T value $(\mathrm{p})$ & \multicolumn{2}{|c|}{$3.99(0.001)$} \\
\hline
\end{tabular}


Table (3): Mean and standard deviation of total energy daily intake (kilocalories) according to the age among diabetic dyslipidemic group before and after NEP, compared with the recommended dietary allowance (RDA).

\begin{tabular}{|c|c|c|c|c|c|}
\hline $\begin{array}{l}\text { Food } \\
\text { group }\end{array}$ & $\begin{array}{l}\text { Age } \\
\text { group }\end{array}$ & & $\begin{array}{l}\text { Dyslipidemic } \\
\text { before NEP }\end{array}$ & $\begin{array}{l}\text { Dyslipidemic } \\
\text { After NEP }\end{array}$ & $\begin{array}{l}\text { Total energy } \\
\text { (kilocalories) } \\
\text { RDA }\end{array}$ \\
\hline \multirow{6}{*}{$\begin{array}{l}\text { Total } \\
\text { energy }\end{array}$} & \multirow[t]{2}{*}{$8-10$} & $\begin{array}{l}\text { Mean } \\
\text { No. }\end{array}$ & $\begin{array}{l}2076.0 \pm 0.0 \\
2\end{array}$ & $\begin{array}{l}2191.0 \pm 0.0 \\
2\end{array}$ & 2000 \\
\hline & & $\mathrm{F}, \mathrm{P}$ & - & & \\
\hline & \multirow[t]{2}{*}{$10-12$} & $\begin{array}{l}\text { Mean } \\
\text { No. }\end{array}$ & $\begin{array}{l}1347.75 \pm 512.6 \\
8\end{array}$ & $\begin{array}{l}1662.0 \pm 243.7 \\
8\end{array}$ & $\begin{array}{l}2500 \text { (Males) } \\
2200 \text { (females) }\end{array}$ \\
\hline & & $\mathrm{F}, \mathrm{P}$ & 2.32 & 0.103 (non significant) & \\
\hline & \multirow{2}{*}{$12-15$} & $\begin{array}{l}\text { Mean } \\
\text { No. }\end{array}$ & $\begin{array}{l}1609.4 \pm 494.8 \\
20\end{array}$ & $\begin{array}{l}1833.4 \pm 255.9 \\
20\end{array}$ & $\begin{array}{l}3000 \text { (males) } \\
2200 \text { (females) }\end{array}$ \\
\hline & & $\mathrm{F}, \mathrm{P}$ & 1.51, & 0.165 (non significant) & \\
\hline
\end{tabular}

Table (4): Mean and standard deviation of total protein daily intake according to the age among diabetic dyslipidemic group before and after NEP and comparison with the recommended dietary allowance.

\begin{tabular}{|c|c|c|c|c|c|}
\hline $\begin{array}{l}\text { Food } \\
\text { group }\end{array}$ & $\begin{array}{l}\text { Age } \\
\text { group }\end{array}$ & & before NEP & After NEP & RDA \\
\hline \multirow{6}{*}{$\begin{array}{c}\text { Total } \\
\text { protein } \\
(\mathrm{gm})\end{array}$} & \multirow[t]{2}{*}{$8-10$} & $\begin{array}{c}\text { Mean } \\
\text { No. }\end{array}$ & $\begin{array}{c}64 \pm 0.0 \\
2 \\
\end{array}$ & $\begin{array}{c}65 \pm 0.0 \\
2\end{array}$ & 28 \\
\hline & & $\mathrm{F}, \mathrm{P}$ & \multicolumn{2}{|c|}{ 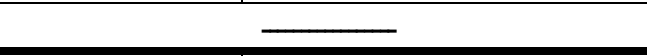 } & \\
\hline & \multirow{2}{*}{$10-12$} & $\begin{array}{l}\text { Mean } \\
\text { No. }\end{array}$ & $\begin{array}{c}40.25 \pm 14.00 \\
8\end{array}$ & $\begin{array}{c}82.75 \pm 17.84 \\
8\end{array}$ & $\begin{array}{c}45 \text { (Males) } \\
46 \text { (females) }\end{array}$ \\
\hline & & $\mathrm{F}, \mathrm{P}$ & 5.09 & 0.15 (non significant) & \\
\hline & \multirow[t]{2}{*}{$12-15$} & $\begin{array}{c}\text { Mean } \\
\text { No. }\end{array}$ & $\begin{array}{c}65.40 \pm 24.78 \\
20 \\
\end{array}$ & $\begin{array}{c}\text { 77. } 1 \pm 15.7 \\
20 \\
\end{array}$ & $\begin{array}{c}59 \text { (males) } \\
44 \text { (females) } \\
\end{array}$ \\
\hline & & $\mathrm{F}, \mathrm{P}$ & 1.50. & 0.168 (non significant) & \\
\hline
\end{tabular}

Table (5): Mean and standard deviation of total Fats daily intake according to the age among diabetic dyslipidemic group before and after NEP .

\begin{tabular}{|c|c|c|c|c|}
\hline $\begin{array}{l}\begin{array}{l}\text { Food } \\
\text { group }\end{array}\end{array}$ & $\begin{array}{l}\text { Age } \\
\text { group }\end{array}$ & & before NEP & After NEP \\
\hline \multirow{6}{*}{$\begin{array}{c}\text { Total } \\
\text { Fat }(\mathrm{gm})\end{array}$} & \multirow[t]{2}{*}{$8-10$} & $\begin{array}{l}\text { Mean } \\
\text { No. }\end{array}$ & $\begin{array}{c}91.00 \pm 0.0 \\
2\end{array}$ & $\begin{array}{c}60.0 \pm 0.0 \\
2\end{array}$ \\
\hline & & $\mathrm{F}, \mathrm{P}$ & \multicolumn{2}{|r|}{ - } \\
\hline & \multirow[t]{2}{*}{$10-12$} & $\begin{array}{l}\text { Mean } \\
\text { No. }\end{array}$ & $\begin{array}{c}41.00 \pm 13.19 \\
8\end{array}$ & $\begin{array}{c}48.0 \pm 6.73 \\
8\end{array}$ \\
\hline & & $\mathrm{F}, \mathrm{P}$ & 0.95 & 0.413 (non significant) \\
\hline & \multirow[t]{2}{*}{$12-15$} & $\begin{array}{l}\text { Mean } \\
\text { No. }\end{array}$ & $\begin{array}{c}65.40 \pm 25.84 \\
20\end{array}$ & $\begin{array}{c}52.30 \pm 12.86 \\
20\end{array}$ \\
\hline & & $\mathrm{F}, \mathrm{P}$ & 1.78, & 0.109 (non significant) \\
\hline
\end{tabular}


Table (6) Mean and standard deviation of total carbohydrates daily intake according to the age among diabetic dyslipidemic group before and after NEP.

\begin{tabular}{|c|c|c|c|c|}
\hline $\begin{array}{l}\text { Food } \\
\text { group }\end{array}$ & $\begin{array}{l}\text { Age } \\
\text { group }\end{array}$ & & before NEP & After NEP \\
\hline \multirow{6}{*}{$\begin{array}{l}\text { Total } \\
\text { carbohydrate } \\
\text { (gm) }\end{array}$} & \multirow[t]{2}{*}{$8-10$} & $\begin{array}{l}\text { Mean } \\
\text { No }\end{array}$ & $\begin{array}{l}243.0 .00 \pm 0.0 \\
2\end{array}$ & $\begin{array}{l}351.00 \pm 0.0 \\
2\end{array}$ \\
\hline & & $\mathrm{F}, \mathrm{P}$ & \multicolumn{2}{|l|}{$\longrightarrow$} \\
\hline & \multirow[t]{2}{*}{$10-12$} & $\begin{array}{l}\text { Mean } \\
\text { No }\end{array}$ & $\begin{array}{l}404.25 \pm 136.21 \\
8\end{array}$ & $\begin{array}{l}227.5 \pm 51.91 \\
8\end{array}$ \\
\hline & & $\mathrm{F}, \mathrm{P}$ & \multicolumn{2}{|c|}{0.63 (non significant) } \\
\hline & \multirow[t]{2}{*}{$12-15$} & $\begin{array}{l}\text { Mean } \\
\text { No }\end{array}$ & $\begin{array}{l}190.10 \pm 71.82 \\
20\end{array}$ & $\begin{array}{l}265.5 \pm 52.40 \\
20\end{array}$ \\
\hline & & $\mathrm{F}, \mathrm{P}$ & 2.79 & ificant) \\
\hline
\end{tabular}

Table (7): Mean and standard deviation of total fiber daily intake according to the age among diabetic dyslipidemic group before and after NEP.

\begin{tabular}{|c|c|c|c|c|}
\hline $\begin{array}{l}\text { Food } \\
\text { item }\end{array}$ & $\begin{array}{l}\text { Age } \\
\text { group }\end{array}$ & & before NEP & After NEP \\
\hline \multirow{6}{*}{ Fibers } & $8-10$ & $\begin{array}{l}\text { Mean } \\
\text { No. }\end{array}$ & $\begin{array}{c}5.4 \pm 0.0 \\
2\end{array}$ & $\begin{array}{c}8.2 \pm 0.0 \\
2\end{array}$ \\
\hline & & $\mathrm{F}, \mathrm{P}$ & \multicolumn{2}{|c|}{ 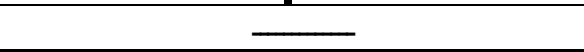 } \\
\hline & \multirow[t]{2}{*}{$10-12$} & $\begin{array}{c}\text { Mean } \\
\text { No. }\end{array}$ & $\begin{array}{c}6.8 \pm 3.43 \\
8\end{array}$ & $\begin{array}{c}9.6 \pm 5.19 \\
8\end{array}$ \\
\hline & & $\mathrm{F}, \mathrm{P}$ & 2.62, & 0.001 (significant) \\
\hline & \multirow[t]{2}{*}{$12-15$} & $\begin{array}{l}\text { Mean } \\
\text { No. }\end{array}$ & $\begin{array}{c}7.2 \pm 4.53 \\
20\end{array}$ & $\begin{array}{c}10.1 \pm 5.20 \\
20\end{array}$ \\
\hline & & $\mathrm{F}, \mathrm{P}$ & 2.79 , & 0.001 (significant) \\
\hline
\end{tabular}

\section{Discussion}

Diabetes Mellitus is chronic illness that requires continuous medical care and education to prevent acute complications and to reduce the risk of long term complications (American diabetes Association, 2000).

Linda and Delahanty (1998), studied the clinical significance of medical nutrition therapy in achieving diabetes outcomes, found statistically significant response after 3 months of medical nutrition therapy. Kulkarni et al. (1998), had conducted a study on nutrition practice guidelines for Type I DM positively affect patients outcomes through education dietetic practice group utilizing 24 patients with IDDM and followed up them for a three months period.
In the studied children, there was statistically significant difference between dyslipidemic and non dyslipidemic groups in all lipid parameters before the program.

After the program, the mean serum cholesterol \& triglyceride level in dyslipidemic children was significantly decreased. The mean serum LDL was not statistically decreased and serum HDL Level was increased but the result was statistically insignificant. Lack of statistically significant results as regards serum levels of LDL\& HDL may be explained by the short duration of the program, three months were not enough to demonstrate the beneficial effects of the diet therapy on the LDL\& HDL levels in these groups. 
Results of this study are in accordance with Glasgow et al. (1996), who studied the effects of a brief office based intervention to facilitate diabetes dietary self management, reported that there was significant differences $(p<0.001)$ favoring intervention on changes in serum cholesterol levels following 3 months intervention program . Aikhailichenko, et al. (1998), studied the lipid metabolic disorder in diabetics, supported the present results as he reported that in patients with IDDM, hyperlipoproteinemia (HLP) was developing in the presence of noncompensated carbohydrate metabolism, with the duration of the disease aggravating the severity of HLP \& he also, suggested that lipid metabolism may change to normal by correction of carbohydrate metabolism. Marja et al. (1983), studied the response of serum lipids and lipoproteins to a high carbohydrate, high fiber, low fat diet (using $50-60 \%$ of total energy intake as CHO and only $15-20 \%$ as fat and the diet contained about 25-28 gram of fiber per $2000 \mathrm{Kcal}$ ). In spite of the short time of the study (6 weeks) found that there was reduction on total Cholesterol $(\mathrm{P}<0.05)$, LDL cholesterol $(\mathrm{P}<0.001)$ and HDL cholesterol $(\mathrm{P}<0.05)$.

A poor control of diabetes, reflected by high levels of glycosylated hemoglobin and/or high fasting blood glucose, was associated with statistically significant increases in total cholesterol, LDLcholesterol and triglycerides, and a reduction in HDL-cholesterol ( Wadwa et al.,2005).

In the current study fasting blood glucose (FBG) \& glycosylated hemoglobin (HbAlc) levels were taken before the diet therapy program for both groups, there was no statistically significant difference between them because both were diabetics.

After the diet therapy program, the mean value of FBG was not significantly decreased, however; the mean value of $\mathrm{HbA1c}$ was decreased significantly.

These data support the hypothesis that poor control of blood glucose is associated with atherogenic lipid profiles.

The current study was in agreement with Eman (1994), who studied the role of diet and nutrition education in managing diabetes in children and she found that there was highly significant decrease of $\mathrm{HbAl}$
$(\mathrm{P}=0.001)$ after nutrition education program (NEP) of about 12 weeks. Also in the same study FBG was not significantly decreased. These findings were also supported by Linda and Delahanty (1998), they found clinically significant meaningful results after three months of dietary practice guidelines, as mean of HbA1 level decreased from 9.15 to 8.15. Kulkarni et al. (1998), in his study achieved greater reduction of $\mathrm{HbA} 1$ level at three months of practice guidelines. Marja et al. (1983), reported reduction of fasting blood glucose and $\mathrm{HbA}$ lafter a short duration of 6 weeks of high carbohydrate, low fat and high fiber diet.

The present results do not agree with Glasgow et al. (1996) and Lorini et al. (1990), who studied the effects of a brief office, based intervention to facilitate diabetes dietary self management and reported that there was no significant difference favoring intervention on changes in HbA1 levels following 3 months intervention program.

The failure to find congruence between self care behavior change and glycemic control outcomes is not unusual and may be mediated by a variety of factors, including degree of insulin resistance, diabetes medication regimen, influence of comorbid factors, and duration of diabetes (Johnson, 1993).

The results of the dietary intake showed that, for total energy, most children in all age groups received inadequate caloric intake. After NEP, the caloric intake was increased insignificantly for all age groups.

Our finding was in agreement with Eman (1994), who found that there was severe deficiency in caloric intake in all age groups in IDDM children\& showed a slightly higher energy intake after NEP, but it was not in accordance with Greg et al. (1996), who found that the mean intake of energy of children with IDDM was close to the recommended levels. Also, in contrast to this finding, Bloomfield et al. (1990) found that the mean daily energy intake was unchanged after NEP.

For the total protein, intake of all age groups was higher than the recommended daily allowance but it was mainly of plant sources. After NEP, there was mild 
insignificant increase of protein intake of most age groups.

For the total carbohydrates, their intake was adjusted to the RDA in most age groups and the results were increased significantly $(\mathrm{p}=0.021)$ among age group 12-15after NEP.

This finding goes with Eman (1994) who found that the protein intake of all age groups was higher than the RDA and mainly of plant origin, while the carbohydrate intake of all age groups was lower than the RDA and there was significant increase of both after NEP. But disagree with Greg et al. (1996), who reported that protein and carbohydrate intake of IDDM children approach the RDA recommended by ADA.

For the total lipids, lipid intake was higher than the RDA \& decreased in most age groups after NEP. Greg et al. (1996) reported that, total fat intake of IDDM children approach the RDA by NCEP. The present finding was in agreement with Eman (1994) who found that the intake of total lipids for most children was higher than the RDA and there was significant decrease in fat intake in the younger children after NEP. Also, Lorini et al. (1990) supported this finding as they reported that after 3 months of intensive dietary education, carbohydrate intake increased and lipids decreased approaching the recommended levels.

For fiber intake, after NEP the fiber intake increased, but the consumption was still low. Eman (1994) found the same results in her study, and Lorini et al. (1990) reported that there was a slight increase in fiber intake after NEP.

Recommendations suggested by AHA (2003) was (dietary cholesterol <200 $\mathrm{mg}$ /day and saturated fat $<7 \%$ of total calories) initially upon confirmation of hyperlipidemia.

Nutrition therapy for children with IDDM is essential to improve measures of glycemic control and lipoprotein mediated risk for dyslipidemia. More innovative approaches to achieve lifestyle changes are required to meet current recommendations which are likely to produce greater beneficial changes than those observed in our study.

\section{References}

1. Abbott WGH, Swinburn B and Ruotolo G (1990):"Effect of a high-carbohydrate diet, low saturated fat diet in apolipopoetein $\mathrm{B}$ and triglyceride metabolism in Pima infants."J. Clin. Invest., 86 : 642-50.

2. Abraham EC, Huff TA, Cope ND, Wilson JB, et al. (1978): "Determination of the glycosylated hemoglobin (HbA1c) with a new micro column procedure. Suitability of the technique for assessing the clinical management of diabetes mellitus." Diabetes, 27(9):931-7.

3. Allain CC, Poon LS and Chan CS (1974):"Enzymatic determination of total serum cholesterol. "Clin. Chem., 20:470475.

4. American Diabetic Association (1994): "Nutritional recommendations and principles for individuals with D.M." Diabetes care, 17:519-22.

5. American Diabetic Association (1997): "Standard of medical care for patients with Diabetes Mellitus." Diabetes care, 20 (1):106-108.

6. American Diabetic Association (2000): "Standard of medical care for patients with Diabetes Mellitus.” Diabetes care, 23(1):43.

7. American Diabetes Association (2003): "Standards of medical care for patients with diabetes mellitus (Position Statement)." Diabetes Care, 26:S33-S50.

8. American Diabetes Association (2003): "Management of Dyslipidemia in Children and Adolescents with Diabetes." Diabetes care, 26:2194-2197.

9. American Diabetes Association (2007): "Nutrition recommendations and interventions for diabetes: a position statement of the American Diabetes Association." Diabetes Care, 30:S48 -S65

10. Barbara v and James WM (1994): "The pathogenesis and treatment of lipid disorders in diabetes mellitus." in : Joslin,s diabetes mellitus 13 ed.,372-397 by Kahan CR\& Weir GC , Philadelphia Lea \& Febiger.

11. Bell JI and Hockaday TDR (1996): "Diabetes Mellitus." In: Oxford Textbook of Medicine ed. By Weatheral D.J., Ledingham J.G.G. \& W Arrell D.A. Third edition. P: 1448-1465. Oxford University Press.

12. Bloomfield S, Galder JE and Chisholm V (1990): "A project in diabetes education for children." Diabetes Medicine, 7: 137-142.

13. Burstein M (1970):"HDL-cholesterol determination after separation of high 
density lipoprotein. " Lipid Res., 11:583

14. Coulston AM (1994): "Nutrition consideration in the control of diabetes mellitus." Nutri. Today, 29 : 6-11.

15. Day JL and Assal JP (1992): "Education of diabetic patients." In: International Textbook of diabetes Mellitus; ed. By Taskin M.R. \& Nestel (1992). P: 924-37 John Wiley \& Sons.

16. Dean GA, Arner TG and Brendel K A, (1997): Epi-info, version 6, CDC. USA Atlanta, Georg:.

17. De Weerdt I, Visser Ap and Van der veen EA (1991): "Randomized controlled multicentre evaluation of an educational program for IDDM patients effects on metabolic control, quality of life and costs of therapy." Diabetes medicine, 8:338-345.

18. Diabetes control and complication Trials Research group (DCCT) (1993): "Nutrition interventions for intensive therapy in the Diabetes control and complication Trials." J. Am. Diet. Assoc.,93 : 768.

19. Drakin DL (1994): "Cyanomethemoglobin method.” Am. J. Sc., 210: 215.

20. Dunger DBand Edge JA (1995): "Glucose houmeostasis in the normal adolescent." In: Kelnar C.J.H. (ed) childhood and adolescent diabetes. Chapman \& Hall, London, P: 31-46.

21. Edelsten Ad, Highes IA and Oakes (1981): "Height and skeletal maturity in children with newly diagnosed juvenileonset diabetes." Arch. Dis. Child., 56: 4044.

22. Eissenbarth G.S., (1986): “Type I diabetes mellitus. A chronic autoimmune disease.”N. Engl. J. Med., 314: 1360-1368.

23. Eman MM (1994): "The role of diet and nutrition education in managing diabetes in children." Ph.D. Thesis, Faculty of Home Economics Helwan University.

24. Ellisson H Wittels and Antonio M (1992): "Clinical features of ischemic heart disease in diabetes mellitus."'In: International Textbook of Diabetes Mellitus; Ed. By Taskin M.R. \& Nestel: 1487-1496 John Wiley \& Sons.

25. Fossati $P$ and Prencipe $P$ (1982) :"Enzymatic determination of triglycerides." Clin.Chem., $28: 2077$.

26. Franz MJ, Bantle JP, Beebe CA, et al. (2002): "Evidence-based nutrition principles and recommendations for the treatment and prevention of diabetes and related complications." Diabetes Care, 25:148-168.
27. Friedewald WT, Levy RI and FredriekSon DS (1972): "Estimation of concentration of low density lipoproteins separated by three different methods." Clin. Chem., 28: 2077.

28. Glasgow RE, Toobert DJ\& Hampson SE (1996): "Effect of brief office-based intervention to facilitate diabetes dietary self management." Diabetes care, 19(8): 835-42.

29. Greg A., Jeannie $M$ and Barbara $M$ (1996): "The dietary intake of children with IDDM." In Medical Nutrition Therapy of children with diabetes." Diabetes care, 19, (12):1370-1374.

30. Gregory JW and Taylor R (1995): "Biochemistry and intermediate metabolism." In: Kelnar C. J.H. (ed) childhood and adolescent diabetes. Chapman \& Hall, London., P: 191-210.

31. Kavey REW, Daniels SR, Lauer RM, Atkins DL, Hayman LL and Taubert K (2003): "American Heart Association guidelines for primary prevention of atherosclerotic cardiovascular disease beginning in childhood." Circulation, 107:1562-1566.

32. Ibrahim B and Arab MM (1992): "Incidence of diabetes mellitus below the age of 15 in Alexandria." Master Thesis, University of Alexandria.

33. Jennifer BB, Katherine M B, Sarah FB, Esther A B, and Denis D M (2004): "Dietary management of children with type I diabetes." Canadian Journal of diabetes, 28(3):219-225.

34. Johnson SB (1993): "Compliance and control in IDDM patients; does behavior really make a difference" In: Developmental aspects of Health Compliance Behavior. Krasneger N.A., Epstein L.\& Johnson S.B., Eds. Hillsdale, N.J. \& Lawrence E., P: 275-297.

35. Kulkarni K, Castle G and Holmes A (1998): "Nutrition Practice Guidelines for type I Diabetes Mellitus positively affect patient outcomes. The Diabetes care and Education Dietetic Practice Group.”J. Am. Diet. Assoc., 98 (1): 62-70.

36. Linda $M$ and Delahanty RD (1998): "Clinical significance of medical nutrition therapy in achieving diabetes outcomes and the importance of the process." Journal of American Dietetic Association, 98 (1): 7075.

37. Lorini R, Ciriaco $O$ and Salvtoni A (1990): "The influence of dietary education in diabetic children." Diabetes Research and clinical practice, 9(3): 279-285. 
38. Marja R, Taskinen $\mathbf{E}$ and Anneli $\mathbf{O}$ (1983): "Serum lipids and lipoproteins in IDDM during high carbohydrate, high fiber diet.’Diabetes Care, 6(3): 50-61.

39. Mikhailichenko TE, Shtoda LA and Chernii VV (1998): "A lipid metabolic disorder in diabetics." Lik. Sprava., 4 (6):85-88.

40. Morsi A., (1997): "Epidemiology of diabetes mellitus in Egypt" Egyptian J. of Diabetes, 2 (1).

41. National Cholesterol Education Program (NCEP) (1988): "The Expert panel, Nutritional cholesterol education program, National heart, lung and B1. Institute, detection, evaluation, and treatment of high B1. Cholesterol" Arch. Intern. Med., 88 (148):36-69

42. NCEP Expert Panel on Blood Cholesterol (1992): Levels in children and adolescents: National Cholesterol Education Program (NCEP): highlights of the Report of the Expert Panel on Blood Cholesterol Levels in Children and Adolescents. Pediatrics, 89:495-501.

43. Orchard T, Forrest KYZ, Kuller L and Becker D (2001): Lipid and blood pressure treatment goals for type1diabetes:10-year incidence data from the Pittsburgh Epidemiology of Diabetes Complication Study. Diabetes Care, 24:1053-1059.
44. Perry TL, Mann JI, Lewis-Barned NJ, Duncan AW, Waldron MA and Thompson C (2008): Lifestyle intervention in people with insulindependent diabetes mellitus (IDDM), J Clin Endocrin Metab., 12:1210-1270.

45. Ronald KC and Gordon CW (1994): "The pathophysiology and treatment of lipid disorders in DM Exercise \& diabetes." In: Joplin's Diabetes Mellitus; $13^{\text {th }}$ edition P: 372-663 Philadelphia lea \& Febiger.

46. Sperling A (1996): "Diabetes Mellitus." In: Nelson Textbook of pediatrics; by Richard E., Robert M.\& Ann M. (1996), $15^{\text {th }}$ edition P: 1646-1666 W.B. Saunders Company.

47. SPSS, (2001): Soft ware program, version 8.

48. Trinder P (1969): Determination of blood glucose using an oxidase-peroxidase system with a non- carcinogenic chromogen. J Clin Pathol., 22(2):158-61.

49. Torres TM, Lerman GI and Bravo RL (1993): "Metabolic control and the prevalence of dyslipidemia in children and adolescents with IDDM." Rev. Invest. Clin., 45(6): 545-52.

50. Wadwa RP, Gregory LK, David M M, Janet S-B, John EH, Satish KG, et al. ( 2005): "Awareness and Treatment of Dyslipidemia in Young Adults With Type 1 Diabetes. "Diabetes Care, 28:1051-1056. 


\section{تأثير النظام الغذائى على دهون الام فى الاطفال المصابين بمرض السكر

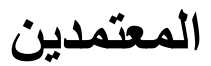 على الانسولين \\ أسماء محمود عبد الله*- زينب بكرى *ـ محمد محمود عبد الوهاب

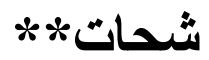 \\ * قسم التغذية الإكلينيكية- معهد التغذية ** قسم علم الحيوان- كلية العلوم جامعة الازهر (باسيوط)}

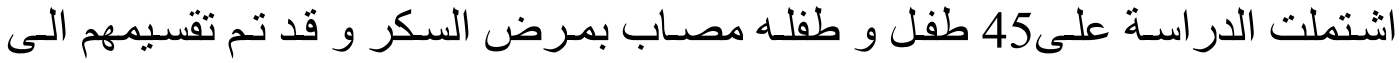

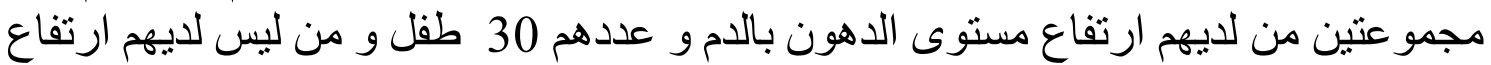

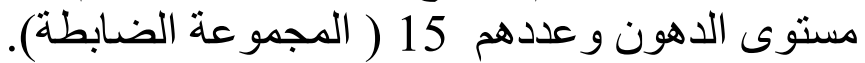

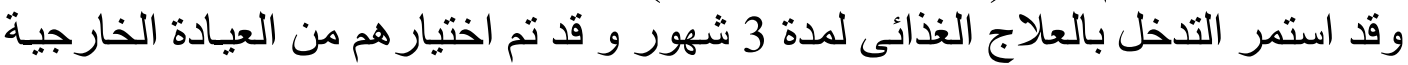

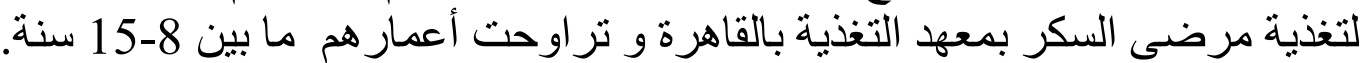

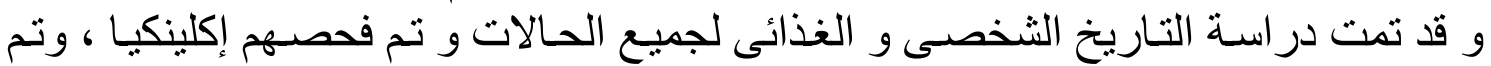

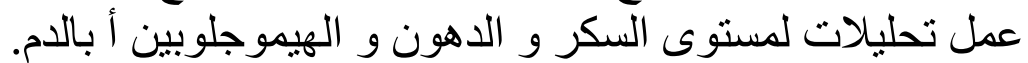

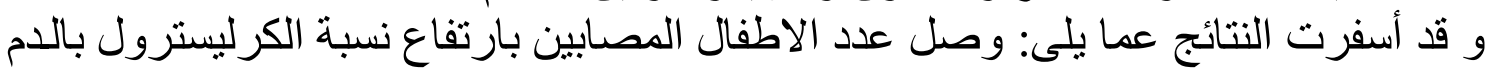

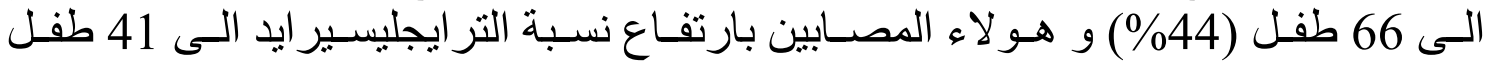

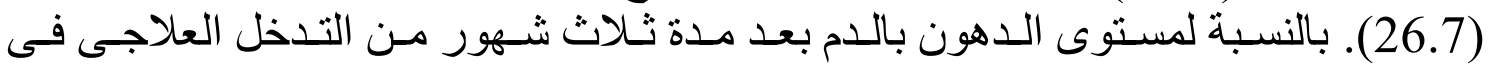

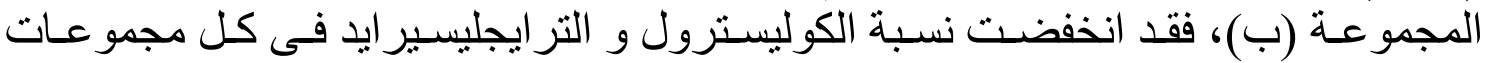

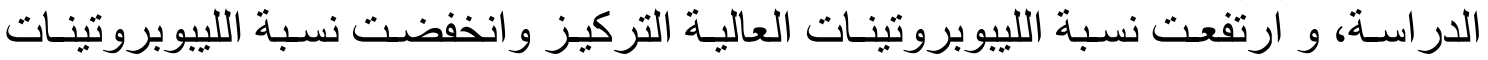

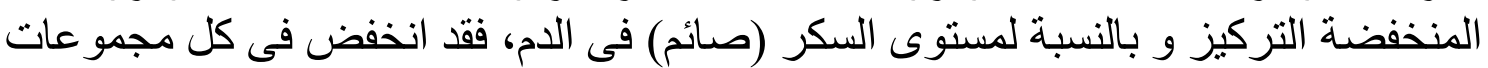

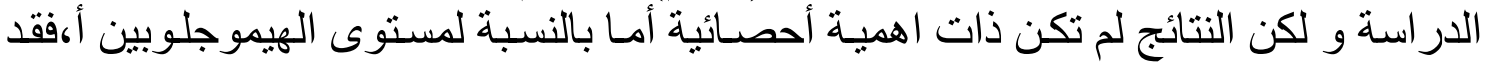

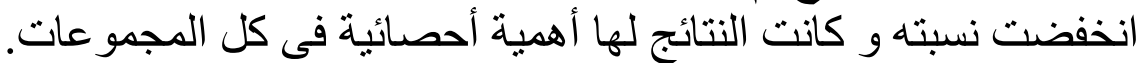

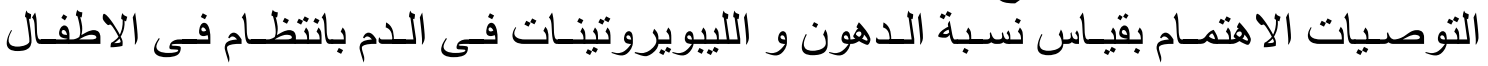

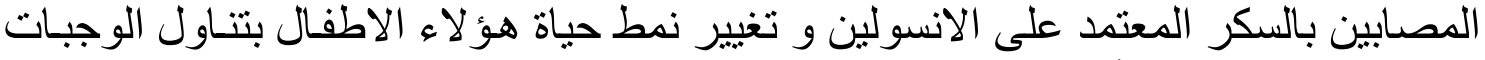

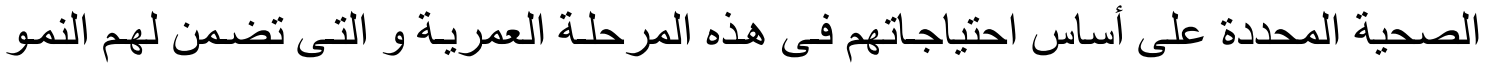

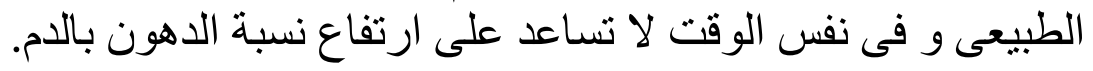

